\title{
APPLICATION OF OXAZOLIDINE IN WET-WHITE TANNING
}

\author{
Vania F.M. SILVA*, António CRISPIM, Gilberto PINTO
}

CIETI/ISEP - Centre of Innovation on Engineering and Industrial Technology/IPP School of Engineering, Rua Dr. António

Bernardino de Almeida, 831, 4200-072 Porto, Portugal

\section{APPLICATION OF OXAZOLIDINE IN WET-WHITE TANNING}

ABSTRACT. The commitment to sustainable development has been one of the main concerns of the world. In this sense, this work aims to develop a process for the application of oxazolidine in wet-white tanning and its viability for increasing the thermal stability of leather, reducing in this way the environmental impact of the tanning process. In order to achieve the higher shrinkage temperature, different parameters have been tested, such as time of reaction of the gluteraldehyde; the time of reaction and concentration of oxazolidine; the effect of synthetic and vegetable tannins at different conditions. Important conclusions were achieved, such as the direct relation between thermal stability and oxazolidine concentration, and the direct relation with the application time of tannins. The main result, a shrinkage temperature of $84.2^{\circ} \mathrm{C}$, was obtained with a concentration of $6 \% \mathrm{w} / \mathrm{w}$ of oxazolidine and a contact time of 8 hours. Although the shrinkage temperature is high, there are still many improvements that must be done to achieve higher stability and then be exported to a pilot scale. KEY WORDS: oxazolidine, shrinkage temperature, glutaraldehyde, leather

\section{APLICAREA OXAZOLIDINEI LA TĂBĂCIREA PIELII WET-WHITE}

REZUMAT. Angajamentul faţă de dezvoltarea durabilă este una dintre principalele preocupări ale lumii. În acest sens, această lucrare îşi propune să dezvolte un proces pentru aplicarea oxazolidinei la tăbăcirea wet-white şi viabilitatea acesteia pentru creşterea stabilităţii termice a pielii, reducând astfel impactul procesului de tăbăcire asupra mediului. Pentru a obţine o temperatură de contracţie mai mare, s-au testat diferiţi parametri, cum ar fi reacţia gluteraldehidei în timp, timpul de reacţie şi concentraţia oxazolidinei, efectul taninurilor sintetice şi vegetale în diferite condiţii. S-au obţinut concluzii importante, cum ar fi relaţia directă între stabilitatea termică şi concentraţia de oxazolidină şi relaţia directă cu timpul de aplicare a taninurilor. Rezultatul principal, o temperatură de contracţie de $84,2^{\circ} \mathrm{C}$, a fost obţinut cu o concentraţie de $6 \%$ oxazolidină în greutate şi un timp de contact de 8 ore. Deşi temperatura de contracţie este ridicată, se pot face multe îmbunătăţiri pentru a obţine o stabilitate mai mare, având posibilitatea apoi să se aducă procesul la scară pilot.

CUVINTE CHEIE: oxazolidină, temperatura de contracţie, glutaraldehidă, piele

\section{L'APPLICATION D'OXAZOLIDINE DANS LE TANNAGE WET-WHITE}

RÉSUMÉ. L'engagement en faveur du développement durable a été l'une des principales préoccupations du monde. En ce sens, ce travail vise à développer un procédé d'application de l'oxazolidine dans le tannage wet-white et sa viabilité pour augmenter la stabilité thermique du cuir, réduisant ainsi l'impact environnemental du processus de tannage. Afin d'atteindre la température de rétraction supérieure, différents paramètres ont été testés, tels que le temps de réaction du glutaraldéhyde, le temps de réaction et la concentration d'oxazolidine, l'effet de tanins synthétiques et végétaux dans différentes conditions. Des conclusions importantes ont été tirées, telles que la relation directe entre la stabilité thermique et la concentration en oxazolidine et la relation directe avec le temps d'application des tanins. Le résultat principal, une température de rétraction de $84,2^{\circ} \mathrm{C}$, a été obtenu avec une concentration de $6 \%$ en poids d'oxazolidine et un temps de contact de 8 heures. Bien que la température de rétraction ait été élevée, de nombreuses améliorations doivent encore être apportées pour atteindre une plus grande stabilité et pour ensuite porter le processus à une échelle pilote.

MOTS CLÉS: oxazolidine, température de rétraction, glutaraldéhyde, cuir

\footnotetext{
* Correspondence to: Vânia F.M. SILVA, CIETI/ISEP - Centre of Innovation on Engineering and Industrial Technology/IPP School of Engineering, Rua Dr. António Bernardino de Almeida, 831, 4200-072 Porto, Portugal, E-mail: vfmsi@isep.ipp.pt, Tel +351 228340500.
} 


\section{INTRODUCTION}

Over the last few years, the commitment to sustainable development has been the main concern of the world, in order to reduce the environmental impact on ecosystems and human health. One of the industries that has been directly affected by these measures is the tanning industry.

Characterized as one of the most polluting industries due to the high quantities of waste generated, this industry has been highly studied by researchers looking for new and less harmful strategies to transform the hide into leather.

Traditionally, the tanning process applies chromium salts as a tanning agent [1], where " $85 \%$ of all leathers are produced with a chrome based process technology" [2]. With higher stability to thermal exposure (above 100 degrees), enzymatic attack and thermomechanical stress [3] and excellent flexibility [4], the chrome-tanned leather is the base process for "almost all types of leathers" [5].

However, the use of chromium salts results in low chromium exhaustion in the tanning bath and a significant presence in the solid waste [6]. This fact requires new research for tanning agents, with the same capacity for producing stable leather. There are several types and combinations of tanning agents that can be considered including mineral agents (aluminium, zirconium), vegetable agents and aldehydes [7].

New studies suggest the use of oxazolidine as an example of an aldehydic tanning agent, which results from the reaction of aldehydes with amino-hydroxy compounds [8, 9]. This product is considered a good substitute due to its versatility when reacting with condensed tannins (phenols) and proteins (collagen), providing the possibility to introduce it at different phases in the tanning process [10]. The crosslinking reaction starts with the opening of the monocyclic or bicyclic oxazolidine ring to form the N-methylol intermediate [11]. In the presence of a tannin molecule, this compound reacts with the polyphenol ring at the 6 and 8 -position through covalent bonds [10, 12]. In the case of collagen, the reaction occurs with the active groups (amino) from its triple-helical structure [10].

There are two types of oxazolidine which are usually used as tanning agents, type
A (4,4-dimethyl-1,3-oxazolidine) and type $\mathrm{E}$ (1-aza-3,7-dioxabicyclo-5-ethyl $(3,3,0)$ octane). Comparing both oxazolidines, type $\mathrm{E}$ has a high dependence on $\mathrm{pH}$ and a lower reaction rate than oxazolidine $A$ [10]. The need to work at a $\mathrm{pH}$ around 8 for better reactivity of oxazolidine minimizes the positive charge of the collagen amino groups. In addition, it reduces the repulsion between same charges and prevents the swelling that usually weakens the collagen structure [13].

In this context, this work aims to evaluate the viability of oxazolidine in the stability of wetwhite leather, taking into account environmental concerns by avoiding the pickling stage in the tanning process.

\section{EXPERIMENTAL}

\section{Materials and Methods}

The raw material used in this work was a bovine hide obtained from a lot of limed hides, from a Tannery Industry of Portugal, split to a $3.5 \mathrm{~mm}$ of thickness.

All the chemicals used in tanning process were obtained from Indinor, a chemical industry located in Portugal and from Angus Chemicals of the Dow Chemical Company.

The trials were carried out using laboratory drums (LFA-9293, Mathis), with temperature and speed control and all the products quantities were based on the weight of bovine hide.

\section{Tanning Process}

Bovine hides were firstly washed and then delimed with $2.5 \mathrm{wt} \%$ of ammonium sulphate, $0.5 \mathrm{wt} \%$ of Sodium bisulphide, $2 \mathrm{wt} \%$ of acetic acid $(1: 10)$ and $100 \mathrm{wt} \%$ of water at $33^{\circ} \mathrm{C}$, for $30 \mathrm{~min}(\mathrm{pH} \approx 8)$ and then bated with a protease, for the same time and temperature.

The delimed and bated skins were washed and pretanned with the mixture of oxazolidine, water (200wt \%) and fungicide (0.3wt\%) at $35^{\circ} \mathrm{C}$. The $\mathrm{pH}$ was decreased until a $\mathrm{pH}$ of 4.5 , then the skins were tanned with a mixture of $4 \mathrm{wt} \%$ of glutaraldehyde (Fortan $2 \mathrm{GL}$ ) an $0.5 \mathrm{wt} \%$ of a fatliquor (Corilene $\mathrm{HLG}$ ), at $35^{\circ} \mathrm{C}$. After completing this phase, the mixture of $1 \mathrm{wt} \%$ of dispersant (Inditan RS), $0.5 \mathrm{wt} \%$ of fatliquor, $6 \%$ of vegetable extract (Tara and Mimosa (1:1)) was added, then the skins were left overnight. Finally, 
the next day, the drums were running for another hour and the $\mathrm{pH}$ was decreased to between 3.5 and 4.0 with $5 w t \%$ formic acid (1:10).

\section{Effect of Oxazolidine Concentration}

The effect on shrinkage temperature of oxazolidine concentration was tested: $2 \%, 4 \%$, $6 \%$ and $8 \% \mathrm{w} / \mathrm{w}$, at $35^{\circ} \mathrm{C}$ and $\mathrm{pH}$ of 8 .

\section{Effect of Synthetic and Vegetable Tannins at Different Conditions}

The use of synthetic tannin was tested rather than vegetable extracts, and its stage of addition was tested in two ways: trial A was carried out by initially applying $4 \%$ of glutaraldehyde and $0.5 \%$ of fatliquor for 1 hour. Following this $6 \%$ of synthetic tannin and $0.5 \%$ of fatliquor were added and the hides were left running overnight; trial B was carried out by applying the products in reverse order: $6 \%$ of synthetic tannin and $0.5 \%$ of fatliquor for 1 hour and then $4 \%$ of glutaraldehyde and $0.5 \%$ of fatliquor were added and the hides were left running overnight.

The influence of synthetic tannins was evaluated against vegetable tannins and their application time: synthetic tannin for trial C, and vegetable tannin $(3 \% \mathrm{w} / \mathrm{w}$ of mimosa and $3 \% \mathrm{w} / \mathrm{w}$ of tara) for trial $\mathrm{D}$. Another trial, trial $E$, was made with the application of a mixture of synthetic tannin $(10 \% \mathrm{w} / \mathrm{w})$ and tara extract $(10 \% \mathrm{w} / \mathrm{w})$.

The study of tannin application time (trials $C, D, F$ and $G$ ) was also performed, changing the time from 5 hours and 30 minutes (trials $C$ and D) to a contact time of 21 hours (trials $F$ and $G$ ).

For all the trials, the hydrothermal stability of leather was evaluated by the determination of the shrinkage temperature.

\section{Experimental Design for Oxazolidine and Glutaraldehyde Reaction Time Evaluation}

Through a two-level experimental design, different contact times of oxazolidine and glutaraldehyde were tested in order to evaluate their effect on the hydrothermal stability of leather. The tanning process was performed at different contact times, from 1 to 7 hours for glutaraldehyde, and from 4 to 8 hours with oxazolidine. The evaluation of the design took into account the analysis of hydrothermal stability by the determination of the shrinkage temperature.

Table 1: Study of technical conditions in the $2^{2}$ factorial design, with duplicated trials

\begin{tabular}{lcc}
\hline & $\begin{array}{c}\text { Oxazolidine } \\
\text { time }\left(\mathrm{t}_{\mathrm{z}}\right)\end{array}$ & $\begin{array}{c}\text { Glutaraldehyde } \\
\text { time }\left(\mathrm{t}_{\mathrm{G}}\right)\end{array}$ \\
\hline Level -1 & $4 \mathrm{~h}$ & $1 \mathrm{~h}$ \\
Level 0 & $6 \mathrm{~h}$ & $4 \mathrm{~h}$ \\
Level +1 & $8 \mathrm{~h}$ & $7 \mathrm{~h}$ \\
\hline
\end{tabular}

Hydrothermal Stability of Leather

The hydrothermal stability of leather was evaluated by the determination of the shrinkage temperature, measured in a small strip of leather with an area of $10 \mathrm{~cm}^{2}$. The samples were immersed in a water bath, at a controlled temperature for 3 minutes. The rate of heating was maintained at $2^{\circ} \mathrm{C}$ after 3 minutes of immersion.

The temperature at which the strip of leather shrunk more than $5 \%$ of its area was taken as the shrinkage temperature.

\section{RESULTS AND DISCUSSIONS}

The effect of oxazolidine offer by the shrinkage temperature obtained for 2, 4, 6 experiments and $8 \% \mathrm{w} / \mathrm{w}$ is shown in Figure 1.

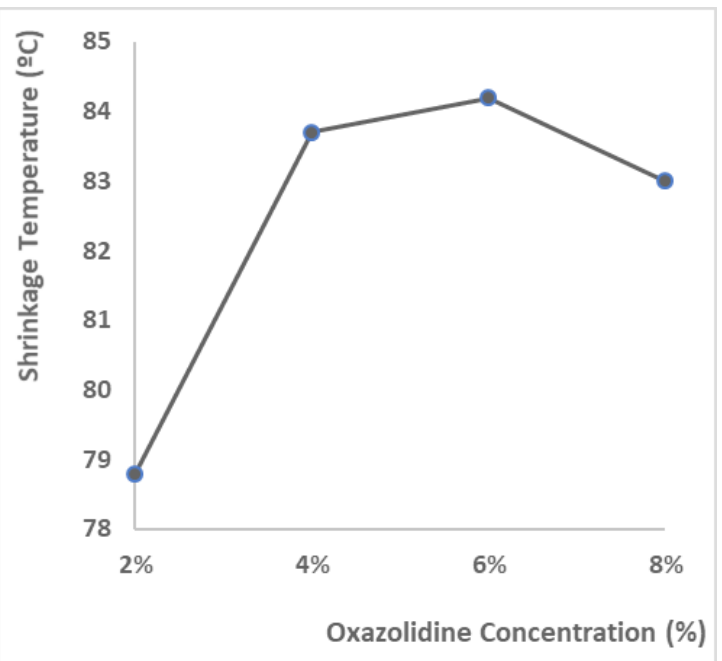

Figure 1. Effect of oxazolidine offer on shrinkage temperature

From the figure it can be seen that a shrinkage temperature of $84.2^{\circ} \mathrm{C}$, for $6 \% \mathrm{w} / \mathrm{w}$ of oxazolidine, is the highest result.

It is also observed that there is a direct relationship between the concentration and the 
thermal stability of leather. However, when the concentration is over $6 \%$, oxazolidine reactivity decreases with a corresponding decrease in the shrinkage temperature.

Comparing the present results with those found in the literature [13], only the use of $2 \%$ and $4 \%$ of oxazolidine were reported with shrinkage temperature values of $78.8^{\circ} \mathrm{C}$ and $83.7^{\circ} \mathrm{C}$, respectively, which approximate those obtained in this work.

Nevertheless, the concentration of $6 \%$ $\mathrm{w} / \mathrm{w}$ of oxazolidine is the obvious choice for further tests.

For the second phase of the work, the effect of synthetic tannins and vegetable tannins at different conditions, both trials $A$ and $B$ shrunk at the same temperature, $80.2^{\circ} \mathrm{C}$, showing that there is no difference when using either the synthetic tannin or the glutaraldehyde first.

Figure 2 shows the result for comparison of synthetic tannins and vegetables extracts.

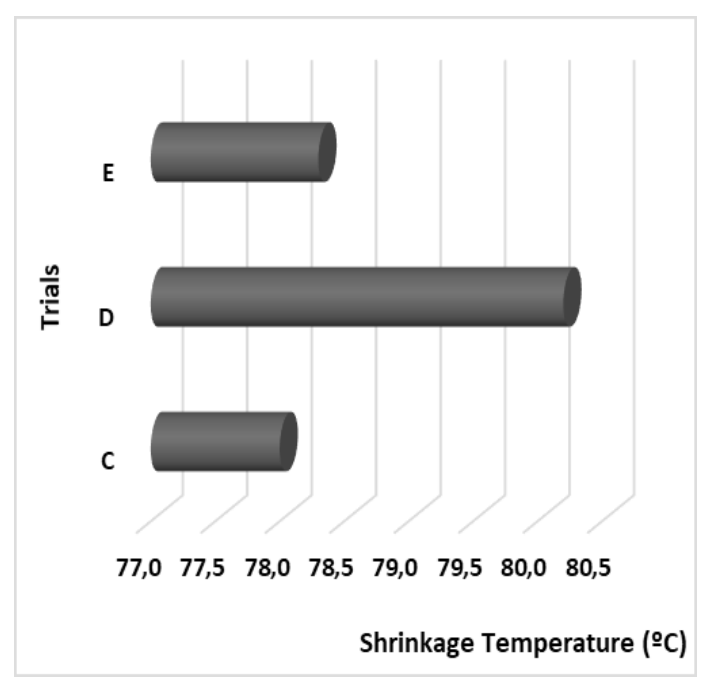

Figure 2. Effect of tannins on shrinkage temperature

It can be seen that the trial with vegetable tannins (trial D) led to the best result, a shrinkage temperature of $80.2^{\circ} \mathrm{C}$, while trial $\mathrm{C}$, using synthetic tannin, had the lowest shrinkage temperature, $78.0^{\circ} \mathrm{C}$. This result is similar to the one of trial $\mathrm{C}$ (mixture of tannins), for which the leather shrank at $78.3^{\circ} \mathrm{C}$.

For the study of tannin application time, Figure 3 shows the shrinkage temperature results, where it is possible to evaluate if the time has some effect on the leather stability.

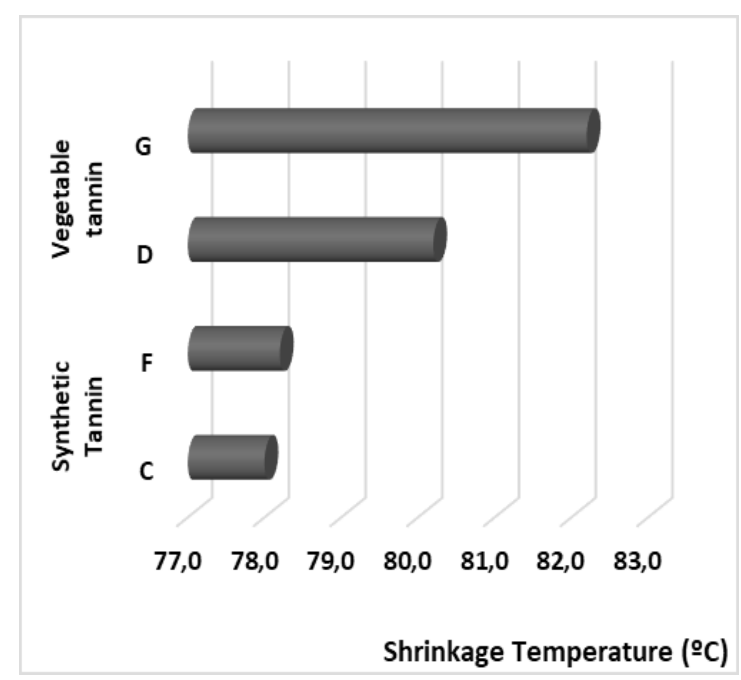

Figure 3. Effect of tannin application time on shrinkage temperature

Comparing the results shown in Figure 3, it is possible to observe that the highest contact time (trial $\mathrm{F}$ and trial $\mathrm{G}$ ) led to the highest shrinkage temperature and both trials, with vegetable extracts, present the best results for thermal stability when compared with synthetic tannin. Therefore, the thermal stability of leather is greater after applying the tannins for longer periods.

\section{Experimental Design for Oxazolidine and Glutaraldehyde Reaction Time Evaluation}

To evaluate the effect of the contact time on the hydrothermal stability of leather, different conditions were evaluated in a total of ten experiments. All possible combinations of factors were used, and a matrix was established according to their low and high levels, represented by -1 and +1 , respectively (Table 2 ).

Table 2: Factorial design

\begin{tabular}{lcccccccccc}
\hline & Test1 & Test2 & Test3 & Test 4 & Test 5 & Test 6 & Test 7 & Test 8 & Test 9 & Test 10 \\
\hline Oxazolidine time $\left(\mathrm{t}_{\mathrm{z}}\right)$ & 1 & -1 & 1 & -1 & 1 & -1 & 1 & -1 & 0 & 0 \\
Glutaraldehyde time $\left(\mathrm{t}_{\mathrm{G}}\right)$ & -1 & -1 & 1 & 1 & -1 & -1 & 1 & 1 & 0 & 0 \\
& -1 & 1 & 1 & -1 & -1 & 1 & 1 & -1 & 0 & 0 \\
\hline
\end{tabular}


The average results of the shrinkage temperature for the factorial design experiments are shown in Figure 4.

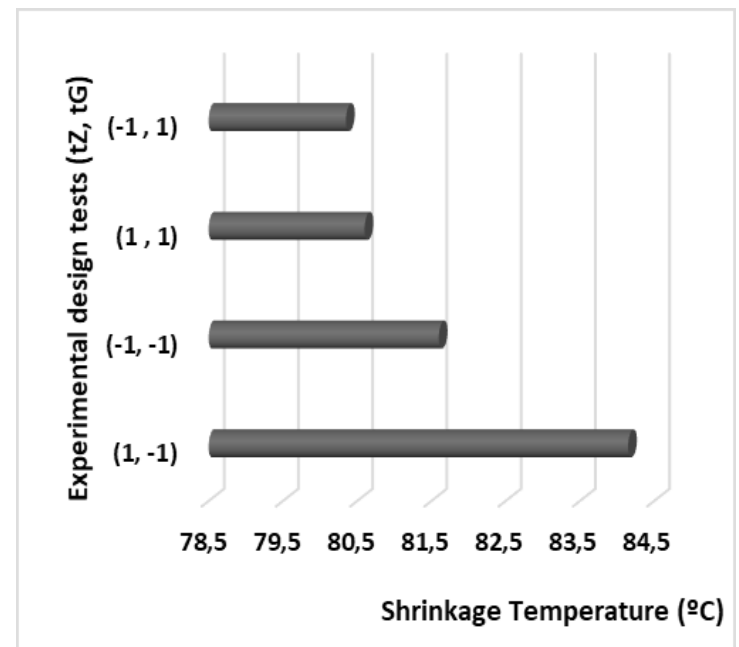

Figure 4. Average results for the experimental design tests

Comparing the results obtained, it can be seen that for the higher shrinkage temperature, $84.2^{\circ} \mathrm{C}$, the relevant factor is the combination of a higher oxazolidine contact time and a lower glutaraldehyde contact time, as shown in Table 3.

Table 3: Statistical parameters for the $2^{2}$ factorial design

\begin{tabular}{lccc}
\hline & $\begin{array}{c}\text { Oxazolidine } \\
\text { time }\left(\mathrm{t}_{\mathrm{z}}\right)\end{array}$ & $\begin{array}{c}\text { Glutaraldehyde } \\
\text { time }\left(\mathrm{t}_{\mathrm{G}}\right)\end{array}$ & $\mathrm{t}_{\text {z. }} \mathrm{t}_{\mathrm{G}}$ \\
\hline Effect & 5.6 & -9.6 & -4.6 \\
Coefficient & 0.7 & -1.2 & 0.575 \\
\hline
\end{tabular}

Considering the two-level factorial design, the defining Equation 1 takes the form:

$$
R=81,38+0,7 t_{z}-1,2 t_{G}-0,575 t_{z_{G}} t_{G}
$$

Due to the lower positive effect of the oxazolidine application time, a change in the values from low to high levels results in an almost insignificant increase in the leather stability. In addition, the glutaraldehyde application time is important because of its negative effect, assuming the main role in this case. At its highest level this factor promotes a decrease of $11,2 \%$ in the shrinkage temperature.

By evaluating the importance of combining the two factors it is possible to observe that the 8 hours of oxazolidine and 7 hours of glutaraldehyde leads to a lower leather stability, when compared with the times of 4 and 1 hours, respectively. This change in time value, from low to high level, results in a reduction of $3 \%$ in the shrinkage temperature.

Thus, by factorial design, the conditions that lead to an optimal result are an oxazolidine time greater than 8 hours and a glutaraldehyde time less than 1 hour.

\section{CONCLUSIONS}

This work studied the application of oxazolidine in wet-white tanning and its suitability for increasing the thermal stability of leather without applying the pickling step in the tanning process. Different conditions were tested, which resulted in a shrinkage temperature of $84.2^{\circ} \mathrm{C}$ for a concentration of $6 \% \mathrm{w} / \mathrm{w}$ of oxazolidine and a contact time of 8 hours, and for $4 \% \mathrm{w} / \mathrm{w}$ of glutaraldehyde with a contact time of 1 hour.

Other important conclusions were achieved, such as the direct relation between thermal stability and oxazolidine concentration, the direct relation with the tannin application time and the best result of vegetable extracts when compared with synthetic tannin.

Nevertheless, there are still many improvements to be made in the process to achieve higher stability. Pilot-scale experiments need to be performed with the best result obtained.

\section{Acknowledgements}

The authors would like to acknowledge Adl (Innovation Agency) for the support of the Project NEWALK - Materials, Components and Technologies for Future Shoes, by QREN National Programme.

\section{REFERENCES}

1. Joseph, K., Nithya, N., J Clean Prod, 2009, 17, 676-682, https://doi.org/10.1016/j. jclepro.2008.11.018.

2. Tegtmeyer, D., Kleban, M., Chromium and leather research - A balanced view of scientific facts and figures, IULTCS, IUR-1 Aug, 2013, 1-10.

3. Sundar, V.J., Rao J. R., Muralidharan C., J Clean Prod, 2002, 10, 69-74, https://doi. org/10.1016/S0959-6526(01)00015-4. 
4. Pu, S., Wang, Y., He, Q., Liao, X., Zhang, W., Shi, B., Int J Quantum Chem, 2012, 112, 28322839, https://doi.org/10.1002/qua.23300.

5. Musa, A.E., Madhan, B., Kanth, S.V., Rao, J.R., Chandrasekaran, B., Gasmelseed, G.A., Clean Technol Envir, 2010, 12, 381-388, https://doi. org/10.1007/s10098-009-0216-5.

6. Lu, Z., Liao, X., Shi, B., J Soc Leath Tech Ch, 2003, 87, 173-178.

7. Sreeram, K.J., Ramasami, T., Resour Conserv Recy, 2003, 185-212, https://doi. org/10.1016/S0921-3449(02)00151-9.

8. Yan, L., Zhaoyang, L., Haojun, F., Yuansen, L., Hui, L., Biyu, P., Bi, S., J Soc Leath Tech Ch, 2009, 92, 252-258.

9. Chen, H., Shana, Z., Int J Biol Macromol, 2010, 46, 535-539, https://doi.org/10.1016/j. ijbiomac.2010.03.001.

10.Choudhury, S.D., Dasgupta, S., Norris, G.E., Int J Biol Macromol, 2007, 40, 351-361, https:// doi.org/10.1016/j.ijbiomac.2006.09.003.

11.http://www.leathermag.com (accessed September 23, 2013).

12. Covington, A.D., Song, L., Suparno, O., Collins, M.J., Koon, H.A., J Soc Leath Tech Ch, 2008, 1-9.

13.Li, K., Chen, H., Wang, Y., Shan, Z., Yang, J., Brutto, P., J Clean Prod, 2009, 17, 1603-1606, https://doi.org/10.1016/j. jclepro.2009.06.004.

(C) 2019 by the author(s). Published by INCDTPICPI, Bucharest, RO. This is an open access article distributed under the terms and conditions of the Creative Commons Attribution license (http:// creativecommons.org/licenses/by/4.0/). 